\title{
Limitation on Maximum Differences in Dispute Settlement Results of Regional Head Selection in the Constitutional Court
}

\author{
Hendrik Syaf Putra; Saldi Isra; Suharizal \\ Faculty of Law, Andalas University, Indonesia \\ http://dx.doi.org/10.18415/ijmmu.v5i6.1043
}

\begin{abstract}
One of the manifestations of the implementation of today's sovereignty is the democraticallyelected regional head of elections which is the mandate of the country's constitution. In the course of the dispute of the result of the election of the head of the area there is a provision of the difference in votes in Article 158 of Law No. 10 of 2016 on the Election of the Governor, the Regent, and the Mayor who constitutes a formal requirement to be able to dispute to the Constitutional Court. The purpose of this study is to analyze the basis of the determination of the threshold for submission of the dispute result of the election of the regional head to the Constitutional Court and how the implications of the sound threshold contained in the election law of the regional head.
\end{abstract}

Keywords: Threshold; Election of Regional Head; Dispute of Result; Constitutional Court

\section{Introduction}

Election is a process to produce leaders who can realize democracy which is a representation of the people, elections are a series of political activities that can accommodate the interests of the community and are formulated in various forms of policy. In other words, the general election is a means of democracy to form a system of state power that is sovereign of the people and the deliberation of representation mandated by the 1945 Constitution of the Republic of Indonesia. Power that is born through election is a power that is born according to the will of the people and is used in accordance with the wishes of the people.

Fundamental changes to regional government regulations based on the amendments to the 1945 Constitution of the Republic of Indonesia are related to filling the position of regional head. Article 18 paragraph (4) states that "Governors, Regents and Mayors respectively as provincial, district and city government heads are democratically elected". Means the basic principle is that the regional head is democratically elected, so whether the regional head is elected directly or indirectly regulated by law. However, it must be recognized that direct election is actually a follow up to the normative realization of democratic principles, namely guaranteeing the operation of the principle of individual freedom and 
equality, especially in political rights. ${ }^{1}$ This provision provides an opportunity to be interpreted that the election of regional heads must be conducted democratically. If the clause "democratically elected" is paralleled by the process of electing the President and Vice President at the national level, then in the regions direct elections for Regional Heads. ${ }^{2}$

The spirit of implementing Direct Regional Head Election is a correction to the indirect democratic system in the previous era, where the Regional Head and Deputy Regional Head are elected by the DPRD to become a democracy that is rooted directly in the people's choice. Therefore, the political decision to hold direct elections of regional heads is a strategic step in order to expand, deepen and improve the quality of democracy. This is also in line with the spirit of autonomy, namely the recognition of regional aspirations and initiatives to determine their own destiny. ${ }^{3}$

In accordance with Article 5 paragraph (3) of the Law on Election of Regional Heads, after the voting stage, vote counting and recapitulation of the results of vote counting, determination of elected candidates, settlement of violations and disputes over election results. The stage of dispute over outcome is the stage where after the determination of the results of the recapitulation of votes for regional head elections, for regional head election participants who are not satisfied with the stipulation can submit the petition for election dispute cases to the Constitutional Court. ${ }^{4}$

Constitutionally, to file a petition for a dispute over the results of the regional head election to the Constitutional Court, the constitutional guarantee from the 1945 Constitution of the Republic of Indonesia is the result of a third amendment, especially in Article 24C paragraph (1) which states that the Constitutional Court has the authority to adjudicate at the first level and finally the final decision to examine the law against the Basic Law, decide upon disputes over the authority of state institutions whose authority is given by the Basic Law, decide upon the dissolution of political parties, and decide on disputes over the results of general elections. The authority of the Constitutional Court to decide disputes over election results is expected to function as a mechanism of control over the performance of the General Election Commission as the organizer of the election, and also to guarantee the principle of justice in elections.

The enactment of article 158 in which there is a provision regarding the threshold provisions on the difference in votes governing the conditions for the vote difference by a certain percentage is a new provision in the procedural law for the election of regional heads to determine the legal standing of the applicant in order to dispute with the Constitutional Court. The threshold provisions are not only contained in the regional head election law, the Constitutional Court also stipulated the threshold provisions in the Constitutional Court procedural law through the Constitutional Court Regulation Number 1 of 2016 concerning amendments to the Constitutional Court Regulation Number 1 Year 2015 concerning Guidelines for Law in Disputes on the Results of Election of Governors, Regents and Mayors. With the Constitutional Court Regulation, the position of the threshold for filing disputes is getting stronger. That is, it can be ascertained that the petition for dispute to the Constitutional Court is very limited.

\footnotetext{
${ }^{1}$ Pratikno, 2005, Demokrasi dalam Pilkada Langsung, Makalah, Sarasehan Menyongsong Pilkada Langsung, Yogyakarta, 25-26 Januari 2005.

${ }^{2}$ Ibid, hlm 233.

${ }^{3}$ Ibid, hlm 42.

${ }^{4}$ Peraturan KPU Nomor 2 tahun 2015 tentang Tahapan, Program, dan Jadwal Penyelenggaraan vide Pemilihan Gubernur dan Wakil Gubernur, Bupati dan Wakil Bupati, dan/atau Walikota dan Walikota, juga telah mengatur sengketa Pemilihan Bupati dan Wakil Bupati serta Walikota dan Wakil Walikota dapat diajukan ke Mahkamah Konstitusi pada tanggal 18- 21 Desember 2015. Sedangkan bagi sengketa Pemilihan Gubernur dan Wakil Gubernur dapat diajukan pada tanggal $19-22$ Desember 2015.
} 


\section{Problem Formulation}

Based on the background above, the problems in this study are:

1. What is the basis for determining the threshold for submitting a dispute request from the Regional Head Election to the Constitutional Court in the Regional Head Election Law?

2. What are the implications of the threshold for submitting a dispute request for the results of a Regional Head Election in the Regional Head Election Law?

\section{Discussion}

The threshold requirement for the difference in vote acquisition is a new rule of law in the regional head election procedures to determine the applicant's legal standing. These rules have been used for the first time since the first simultaneous regional head elections in 2015. In the second simultaneous regional head election in 2017 the Constitutional Court remained consistent in using the provisions contained in Article 158 of Law Number 8 of 2015 as amended in Act Number 10 of 2016 for the Election of Governors, Regents and Mayors to Become the Act in examining and adjudicating to be the formal requirements of the applicant in dispute with the Constitutional Court. This article is, of course, considered by some to limit the disputes over the results of regional head elections. With the applicant's threshold provisions, they can only file a lawsuit if the difference between the votes of the applicant and the winner of the regional elections is $2 \%$. The threshold provisions are stated as follows:

a. Province with a population of up to 2,000,000 (two million) people, filing a vote dispute is made if there is a difference of at most $2 \%$ (two percent) of the total valid votes of the final vote counting result set by the Provincial KPU;

b. Provinces with a population of more than 2,000,000 (two million) up to 6,000,000 (six million), submission of voting disputes is made if there is a difference of at most $1.5 \%$ (one point five percent) of the total valid votes counted the final stage of votes stipulated by the Provincial KPU;

c. Province with a population of more than 6,000,000 (six million) up to 12,000,000 (twelve million) people, filing a vote dispute is made if there is a difference of at most $1 \%$ (one percent) of the total valid votes from the vote counting stage. the end determined by the Provincial KPU; and

d. Province with a population of more than 12,000,000 (twelve million) people, filing a vote dispute is made if there is a difference of at most $0.5 \%$ (zero point five percent) of the total valid votes of the final stage of the vote count determined by the KPU Province;

Participants in the Election of Regents and Deputy Regents and Mayors and Deputy Mayors may submit a request for cancellation of the determination of the results of the vote count with the provisions. ${ }^{5}$

a. Regency / City with a population of up to 250,000 (two hundred and fifty thousand) people, filing a vote dispute is done if there is a difference of at most $2 \%$ (two percent) of the total valid votes of the final stage of the vote count determined by the Regency KPU / City;

b. Regencies / Cities with a population of up to 250,000 (two hundred fifty thousand) people up to 500,000 (five hundred thousand) people, filing a vote dispute is made if there is a

\footnotetext{
${ }^{5}$ Pasal 158 Ayat (2), Undang-Undang Republik Indonesia Nomor 10 Tahun 2016 Tentang Pemilihan Gubernur, Bupati, dan Walikota
} 
difference of at most $1.5 \%$ (one point five percent) of the total valid votes of the final stage of vote counting determined by a Regency / City KPU;

c. Regency / City with a population of up to 500,000 (five hundred thousand) people up to 1,000,000 (one million) people, filing a vote dispute is made if there is a difference of at most $1 \%$ (one percent) from the determination of the results of the vote count by Regency / City $K P U$; and

d. Regency / City with a population of more than 1,000,000 (one million) people, filing a vote dispute is made if there is a difference of at most $0.5 \%$ (zero point five percent) of the total valid votes of the final stage of the vote count determined by Regency / City KPU.

To be able to see the basis for stipulating of article 158 we can refer to the minutes of the formation of the Regional Election Law Number 8 of 2015, we can obtain through public information services by information management officials and documentation of the secretariat of the indonesian peoples representative council. But after the official treatise on the establishment of the Regional Election Law was traced and explored by the author, there were no debates or provisions found. further on the basis for the establishment or formulation of the threshold in Article 158 of the Law on Election of Regional Heads.

However, we can see how the debates and discussions that floated in the public and in the media on the issue of bribery which appear to be a central issue in handling disputes over election results in the Constitutional Court. Here the author can conclude that the basis for the stipulation of Article 158 is to minimize and prevent the Constitutional Court from falling back in the bribery case of the regional head election which can damage the people's sovereignty, because there is no similar and consistent definition of the use of structured, systematic test stones, systematically, and massive.

One of the absolute authority of the Constitutional Court is that the decision of the Constitutional Court is final, that is, the decision of the Constitutional Court directly obtains permanent legal force since it is said and no legal remedies can be taken. The final nature in the decision of the Constitutional Court in this Act also includes binding and final legal force. Whatever the results of the decision of the Constitutional Court can not be done judicial review. With the authority of the Constitutional Court is very large, so it is very vulnerable to corruption and bribery practices, especially those involving disputes over regional head elections. As a note on October 2, 2013, Chief Justice of the Constitutional Court, Akil Mochtar, was arrested by the Corruption Eradication Commission (KPK) related to receiving bribes in handling regional head election cases.

Then the basis for the stipulation of Article 158 is to reduce the accumulation of cases in the Constitutional Court because since the transfer of authority as the adjudication of disputes over the results of regional head elections by the Constitutional Court in 2008, the number of cases in the Constitutional Court tends to increase, eventually becoming the Election Court (Election Court) because the number of regional head election dispute cases handled is more than the judicial review which is the main authority of the Constitutional Court.

If traced the experience of resolving disputes over the results of regional head elections a little back, the space using the Constitutional Court path is not entirely used by pure candidate pairs to correct miscalculations that affect the election of candidate pairs. Some facts show that some of the couples who lost the election process, such as trying to use the path to the Constitutional Court, became a shortcut to correct people's votes. The most striking example, despite the fact that there was a very clear difference in votes, the losing candidate still chose to file a dispute with the Constitutional Court. In fact, within the limits of reasonable reasoning, the difference in votes may not be proven as a result of miscalculation. ${ }^{6}$

\footnotetext{
${ }^{6}$ www.saldiisra.web.id, diakses pada tanggal mei 2017
} 
The choice to use the Constitutional Court path is like changing into a new mode when a reason for multiple interpretations to submit a dispute is a violation that is TSM. For this reason, the resolution of disputes to the Constitutional Court is like a garbage basket, the unpreparedness of the political actors in the contestation to fill the position of regional head accepts people's choice. Although some seem to try, the choice to the Constitutional Court is still being made because some are also trying to take advantage of the possible "wild behavior" of the Constitutional Court judges. At the very least, the experience that befell Akil Mochtar is evidence of this use. ${ }^{7}$

In the span of 2008 up to the end of 2017 the Constitutional Court has decided as many as 1156 cases of disputes over the results of regional head elections, with the results of the decision granted as many as 252 , rejected as many as 405 , unacceptable 359 , withdrawn as many as 112 , and as many as 20 dead. ${ }^{8}$ According to Hamdan Zoelva the petition was granted because in practice, there were massive and even systematic and structured violations. These violations accumulated when brought to the Constitutional Court, which forced the Constitutional Court to find legal reasons to cancel the results of regional head elections. ${ }^{9}$

With so many regional election cases that must be decided by the Constitutional Court each year. Without limitation, the Constitutional Court turned into a pile of dispute resolution cases. This is due to the limited number of constitutional judges (ie nine people) and on the other hand the number of dispute requests that have accumulated, the Constitutional Court must concentrate more on resolving disputes over regional head elections. As a result, the Constitutional Court has limited time to complete constitutional authority, especially judicial review of the constitution as stipulated in Article 24C Paragraph (1) of the 1945 Constitution of the Republic of Indonesia. ${ }^{10}$

Moreover, before being carried out simultaneously, the regional head election agenda is held almost throughout the year. By doing this, the Constitutional Court must also pay attention throughout the year with the obligation to settle disputes for regional head elections. Because of this, I have stated that, if it were carried out without tighter regulation, the parties that could submit local election disputes, the Constitutional Court had the potential to lose the focus of exercising authority in the 1945 Constitution of the Republic of Indonesia, especially judicial review. In fact, as one of the holders of judicial power, judicial review is the crown of the Constitutional Court. ${ }^{11}$

Then that becomes the basis for the stipulation of Article 158 in order to encourage the development of ethics as well as an increasingly mature political culture. With regard to the provisions of Article 158 of the Law on Election of Regional Heads, a test has been conducted to the Constitutional Court, namely by a group of students and a number of state administration law practitioners. The Test Stone for this petition is Article 158 deemed contrary to the provisions of Article 1 paragraph (3), Article 24 paragraph (1), and Article 28D paragraph (1) of the 1945 Constitution of the Republic of Indonesia. The Petitioners reviewing Article 158 of the Regional Head Election Law states that the provisions of Article 158 have caused the losing pair of candidates to not be able to take legal action in the form of a dispute over the results of the regional head election to the Constitutional Court to cancel the victory of the candidate pair participating in the regional head election using the methods ways against the law in an effort to win it. ${ }^{12}$ In other words, the provision of Article 158 has been deemed to provide limitations for regional head election participants so that in regional head elections violations that are systematic,

\footnotetext{
${ }^{7}$ Ibid.

${ }^{8}$. www.mahkamahkonstitusi.go.id, diakses pada tanggal 1 Januari 2018

${ }_{9}$ Hamdan Zoelva, "Problematika Penyelesaian Sengketa Hasil Pemilukada oleh Mahkamah Konstitusi", Jurnal Konstitusi, Volume 10, Nomor 3, hlm 385.

${ }^{10}$ Ibid.

${ }^{11}$ Ibid.

${ }^{12}$ Putusan Nomor 58/PUU-XIII/2015, hlm. 35.
} 
structured and massive, the regional head election participants who are harmed by the violations cannot seek justice in the Constitutional Court. ${ }^{13}$

With regard to the petition for review in Article 158, the Constitutional Court refuses on the grounds that not all restrictions are necessarily contrary to the 1945 Constitution of the Republic of Indonesia, as long as these restrictions are to guarantee recognition, respect for the rights and freedoms of others and to fulfill the demands fair in accordance with moral considerations, religious values, security and public order, then such restrictions can be justified according to the constitution (vide Article 28J paragraph (2) of the 1945 Constitution of the Republic of Indonesia). ${ }^{14}$

According to the Constitutional Court, the limitation for regional head election participants to propose the cancellation of the determination of the results of vote counting in Article 158 of the Regional Head Election Law is an open legal policy forming a law to determine it because such restrictions are logical and legally acceptable because to measure the significance of the acquisition candidate vote. In addition, according to the Constitutional Court "That the rationality of article 158 paragraph (1) and paragraph (2) of Law Number 8 Year 2015 is actually part of the efforts to form laws to encourage the development of ethics and political culture which is becoming more mature, namely by making the formulation of norms of laws in which a person who participate in the constellation of the Election of Governors, Regents and Mayors do not necessarily claim an election result to the Constitutional Court with a calculation that is difficult to be accepted by reasonable reasoning". ${ }^{15}$

In the theory of justice, the relationship between law and justice can also be observed in every legal objective. Starting from the legal goals of ethical teaching, standard priority teachings to caseistic teachings. None of these teachings can escape from the aims of the law on the justice side. It's just equipped with other legal objectives such as certainty, expediency, and predictibility. This includes lawmakers, even though they are consistent in escaping justice as one of the aims of the law, in essence they are still required to formulate a legal theory of justice that can support the importance of certain laws being institutionalized in state institutions. That in every legislation it is always equipped with considerations to weigh, regulate, determine. It should be noted that in the consideration, there are philosophical considerations that record the purpose of law as justice for the formation of the Act. ${ }^{16}$

It must be acknowledged that ethics and political culture are increasingly mature in the process of regional head election so far it has not been too high, it has been proven that so far 85 percent of regional head elections have led to disputes in the Constitutional Court. As one example in January 2010 s.d. December 2010 there were 230 cases registered at the Constitutional Court. The reason for the high submission of disputes over the results of regional head elections to the Constitutional Court even though the difference in the acquisition of very wide votes is basically because in general participants in the regional elections in each declaration at the beginning of the regional head election stage always states to be ready to win and ready to lose it turns out only in words only.

Decision of the Constitutional Court which chooses to apply Article 158 in full because at least the consideration of the authority to examine and adjudicate disputes over the results of regional head elections is an additional authority considering the constitutional authority of the Constitutional Court has been limitatively determined in Article 24C paragraph (1) of the Constitution of the Republic of Indonesia

\footnotetext{
${ }^{13}$ Ibid, hlm. 107.

14 Ibid. Terhadap permohonan Nomor 58/PUU-XIII/2015 Mahkamah Konstitusi menyatakan bahwa pemohon adalah pelajar/mahasiswa yang tidak sedang atau tidak hendak mencalonkan diri sebagai gubernur/wakil gubernur, bupati/wakil bupati, atau walikota/wakil walikota. Dengan demikian Pasal 158 UU Pilkada tidak menimbulkan kerugian terhadap hak konstitusional para pemohon, yang berarti para pemohon tidak memiliki kedudukan hukum (legal standing) untuk bertindak selaku pemohon dalam permohonan ini.

${ }^{15}$ Ibid, hlm. 36

${ }^{16}$ Soedikno Mertokusumo, 2005, Mengenal Hukum, Liberty, Yogyakarta, hlm 78.
} 
as an additional authority, the authority granted by the Regional Election Law to decide on disputes over the results of regional head elections clearly has different qualifications from the authority granted directly by the 1945 Constitution of the Republic of Indonesia. In implementing the authority In addition, the Constitutional Court fully complies with the provisions of the Law on Election of Regional Heads as the source and basis of authority.

Furthermore, according to the Constitutional Court through the Law on Election of Regional Heads, the Formers of the Law have designed such a method for resolving disputes or disputes that occur outside of disputes over the determination of the votes for the vote count results. ${ }^{17}$ Thus, legislators build a legal and political culture so that disputes brought to the Constitutional Court to be examined and tried are truly disputes concerning the determination of the results of vote counting, not disputes or other disputes that have been determined to be the authority of other institutions. ${ }^{18}$

In the short term, submitting all types of disputes or disputes in the regional head election process to the Constitutional Court is indeed felt to be easier, faster, and can meet the people's expectations of justice. However, if this continues to be maintained, in addition to making the Constitutional Court the foundation of everything because all types of disputes or disputes are requested to be examined and tried by the Constitutional Court, the social engineering function in the Law on Election of Regional Heads to build a legal and political culture of the community the more mature become obstructed, even in vain

The existence of Article 158 is a form of social engineering in order to build high legal awareness. This has at least been proven in the 2015 and 2017 regional head elections. In 2015 out of 264 regions that held regional head elections, 132 regions submitted applications to the Constitutional Court. And in 2017 as many as 101 regions held regional head elections, 53 regions submitted applications to the Constitutional Court. Pairs of candidates for governor, regent, or mayor in regions that do not submit applications to the Constitutional Court are likely influenced by awareness and understanding of the provisions of Article 158. This means that the social engineering function of the Election Law for Regional Heads works well.

In the 2017 regional head election, the Constitutional Court continued to consistently apply the vote threshold requirements as stated in Article 158 of Law Number 10 Year 2016 concerning the Election of Governors, Regents and Mayors. The issue of regulating the threshold of the difference in votes is of particular concern in the implementation of regional head elections in Indonesia. This can be seen in at least the last two simultaneous local election editions, namely the 2015 regional head election and the 2017 regional head election. Article 158 The Law on Regional Head Election is the most criticized because it is considered to have violated democratic values by setting limits on disputes with the Court The Constitution is related to the difference in regional head elections.

The number of requests for disputes over the results of regional head elections which were stopped in the preliminary examination process in the Constitutional Court due to the threshold of votes in Article 158 caused differences in public opinion regarding the limitation of the threshold contained in the regional head election law. On the one hand, the Petitioner is of the view that the Constitutional Court as the only judicial institution that is believed to uphold substantive justice must not be constrained by the existence of Article 158 so that it should prioritize a sense of community justice. On the other hand, the respondent (KPUD) and related parties (pair of temporary winners) argued that Article 158 is a law that is still valid and binding on all Indonesian people, including the Constitutional Court, so in carrying out its functions, duties and authorities the Constitutional Court must be guided by on the 1945 Constitution of the Republic of Indonesia and the laws and regulations.

\footnotetext{
${ }^{17}$ Ibid, hlm. 81 .

${ }^{18}$ Ibid.
} 
In response to this, the Constitutional Court is of the opinion that in relation to Article 158 of Law Number 10 Year 2016, the Court may not rule out the enactment of Article 158 of Law Number 10 of 2016 because to rule out Article 158 of Law Number 10 of 2016 is the same as opposing a decision and its own establishment as affirmed in Decision of the Constitutional Court Number 58 / PUU-XIII / 2015, dated July 9, 2015, and Regulation of the Constitutional Court Number 1 of 2016 as amended by Regulation of the Constitutional Court Number 1 of 2017. Similarly, the Court may not rule out the validity of Article 158 of Law Number 10 Year 2016 without confusing the position of the Court as the executor (provisionally) of the Act (in casu of Law Number 10 of 2016) and the position of the Court as a judge of the Act or the position of the Court in exercising other authority handed down from Article 24C of the Basic Law r Republic of Indonesia 1945. ${ }^{19}$

Waiver of the validity of a norm of the Act can only be done by the Court when the Court is exercising the authority granted to it by the Constitution, in casu Article 24C paragraph (1) of the 1945 Constitution of the Republic of Indonesia, not when the Court is implementing the provisions of the Law Invite, as is the case in the a quo case. Therefore, the Court does not agree with the argument of the Petitioner who on the pretext of upholding the last substantive justice "compel" The court to, on the one hand, change its position without a basis of arguments that can be accounted according to the rules of legal reasoning so that it can become a serious problem in the context of justice accountability (judicial accountability) and on the other hand treat other parties unfairly, i.e. those who are aware of the norms specified in Article 158 of Law Number 10 Year 2016 and then decide not to submit an application to the Court, even though they may have stronger arguments or at least as strong as the Petitioner's arguments in the a quo petition., ${ }^{20}$

With the regulation regarding the threshold regulated in Article 158 of the Regional Head Election Law, it has implications for the number of requests for a difference in the votes to the Constitutional Court that fall because they do not cross the threshold of the difference in votes determined by the law. Because as a consideration in the examination of dispute over the results by the Constitutional Court in addition to seeing the applicant's grace period stipulated in Article 157 paragraph (5) of Law Number 10 Year 2016, the Court also sees legal standing as the formal requirements of the applicant in deciding the petition for dispute over the results of regional head elections, namely regarding the provisions of the applicant contained in Article 1 number 3 of Law Number 8 of 2015 and concerning the threshold of the difference in votes stipulated in Article 158 of Law Number 10 of 2016, so that most of the petitioners requests are stopped at the preliminary examination process because does not meet the predetermined vote threshold.

\section{Conclusions}

1. The basis for determining the threshold for submitting a dispute over the results of the Regional Head Election to the Constitutional Court is: First, to prevent the Constitutional Court from falling back in the case of bribery in the case of regional head elections that can claim people's sovereignty because there is no similar and consistent definition of the use of test stones. structured, systematic and massive (TSM); Second, to reduce the accumulation of cases of disputes over regional head elections that are handled by the Constitutional Court; Third; encourage the development of ethics and political culture as well as an increasingly mature in the process of local elections.

\footnotetext{
${ }^{19}$ Putusan Mahkamah Konstitusi Nomor 45/PHP.GUB/XV/2017, hlm 189

${ }^{20}$ Ibid
} 
2. With the application of the threshold for submitting petition disputes over the results of regional head elections to the Constitutional Court Article 158 of Law Number 10 Year 2016 concerning the Election of Governors, Regents and Mayors has a direct implication on the number of requests for disputed claims resulting from regional head elections that do not reach the the final decision stage because the petition for the claim had already been dropped at the advanced examination stage and was terminated in an interim decision / dismissal by the Constitutional Court.

\section{References}

Pratikno, 2005, Demokrasi dalam Pilkada Langsung, Makalah, Sarasehan Menyongsong Pilkada Langsung, Yogyakarta.

Soedikno Mertokusumo, 2005, Mengenal Hukum, Liberty, Yogyakarta.

Hamdan Zoelva, "Problematika Penyelesaian Sengketa Hasil Pemilukada oleh Mahkamah Konstitusi”, Jurnal Konstitusi, Volume 10, Nomor 3.

Undang-Undang Republik Indonesia Nomor 10 Tahun 2016 Tentang Pemilihan Gubernur, Bupati, dan Walikota

Peraturan KPU Nomor 2 tahun 2015 tentang Tahapan, Program, dan Jadwal Penyelenggaraan vide Pemilihan Gubernur dan Wakil Gubernur, Bupati dan Wakil Bupati, dan/atau Walikota dan Walikota.

Putusan Mahkamah Konstitusi Nomor 45/PHP.GUB/XV/2017

Putusan Mahkamah Konstitusi Nomor 58/PUU-XIII/2015

\section{Copyrights}

Copyright for this article is retained by the author(s), with first publication rights granted to the journal.

This is an open-access article distributed under the terms and conditions of the Creative Commons Attribution license (http://creativecommons.org/licenses/by/4.0/). 